\title{
Comparative Analysis of Metal Binding Characteristics of Copper Chaperone Proteins, Atx1 and ATOX1 ${ }^{\dagger}$
}

\author{
Suree Narindrasorasak ${ }^{\ddagger}$, Xuefeng Zhang ${ }^{\ddagger}$, Eve A. Roberts ${ }^{\S}$, and Bibudhendra Sarkar ${ }^{\ddagger}$, \\ ${ }^{\ddagger}$ From the Department of Structural Biology and Biochemistry, The Research Institute of the \\ Hospital for Sick Children, Toronto, Ontario, M5G 1 X8 Ontario Canada and "The Department of \\ Biochemistry, University of Toronto, Toronto, Ontario, M5S 1 A8 Canada. \\ \$Permanent address: Metabolism Research Program, The Research Institute of The Hospital for \\ Sick Children and Department of Pediatrics, Medicine and Pharmacology, University of Toronto, \\ Toronto, Ontario, Canada.
}

\begin{abstract}
The metal binding properties of the human copper chaperone ATOX1 and its yeast homologue Atx 1 have been characterized. Complexes of these proteins with $\mathrm{Cu}(\mathrm{I}), \mathrm{Ag}(\mathrm{I}), \mathrm{Cd}(\mathrm{II})$ and $\mathrm{Hg}(\mathrm{II})$ were studied by native gel electrophoresis, chemical cross-linking followed by SDS-PAGE, as well as by size exclusion chromatography, mutagenesis and UV-visible absorption spectroscopy. Results indicate that binding of different metals to either ATOX1 or Atx1 altered conformation of subunit structure and the oligomerization state of the proteins. Furthermore, it has been demonstrated that freshly reduced apoprotein is capable to convert $\mathrm{Cu}(\mathrm{II})$ to $\mathrm{Cu}(\mathrm{I})$ stoichiometrically to the amount of protein present, while oxidized protein is only twenty per cent as active. Titration of $\mathrm{Cu}(\mathrm{II})$ with either oxidized or reduced protein resulted in similar increase in absorbance at $254 \mathrm{~nm}$, implicating Cu-thiolate formation in both forms of the protein, but titration with $\mathrm{Ag}(\mathrm{I})$ caused the increase in absorbance at $254 \mathrm{~nm}$ with the reduced protein only. These data indicate that $\mathrm{Cu}(\mathrm{I}), \mathrm{Ag}(\mathrm{I}), \mathrm{Hg}(\mathrm{II})$ and $\mathrm{Cd}(\mathrm{II})$ are all capable of binding to ATOXI and Atxl, but the characteristics of the binding to these copper chaperones differ for different metals.
\end{abstract}

\footnotetext{
'Abbreviations: BCA, bicinchoninic acid; BCS, bathocuproinedisulfonic acid; BSA, bovine serum albumin; DTT, dithiothreitol; EDTA, ethylene diamine tetra-acetic acid; GST, glutathione S-transferase; HEPES, N(2-hydroxyethyl)piperazine-N'-2-ethanesulfonic acid, IPTG; isopropyl- $\beta$-D-thiogalactopyranoside; MES, 2 -

${ }^{+}$This work is supported by a grant from the Canadian Institutes of Health Research MOP 1800 to B.S.

* To whom correspondence should be addressed: Department of Structural Biology and Biochemistry, The Hospital for Sick Children, 555 University Ave., Toronto, Ontario, M5G IX8 Canada. Tel: 416-813-5921, Fax: 416-813-5022, email: bsarkar@sickkids.on.ca
} 
(N-morpholino)ethanesulfonic acid; PAR, 4-(2-pyridylazo)resorcinol; PMSF, phenylmethylsulfonyl fluoride; SDS-PAGE, SDS polyacrylamide gel electrophoresis; Tris, tris(hydroxymethyl)amminomethane.

\section{INTRODUCTION}

Copper is an essential trace element in all living organisms. It plays a crucial role in cellular respiration, antioxidant defense and iron metabolism in eukaryotes /1/. Since free intracellular copper can be toxic even at low concentrations, specialized systems for transport and homeostatic mechanisms are required to maintain safe intracellular concentrations of this metal inside the cells. Insight into the mechanism of copper trafficking has followed the characterization of genes involved in the inherited copper disorders, Wilson and Menkes diseases /2-5/. Despite strikingly different clinical phenotypes, each disease results from absence or dysfunction of homologous copper transporting ATPases located in the trans-Golgi network of cells for transporting copper to the secretory pathway and cellular export /6-10/. In Wilson disease, toxic amounts of copper accumulate in liver and brain, resulting in hepatic cirrhosis and neuronal degeneration. Menkes syndrome is characterized by a profound copper deficiency state which results in the failure to incorporate copper into essential copper containing enzymes /11/. Studies on a similar ATPase, Ccc2p in Saccharomyces cerevisiae have revealed a remarkable conservation of mechanisms of copper metabolism /12/.

A series of genetic studies in Saccharomyces cerevisiae has revealed that the delivery of copper to specific cellular pathways is mediated by a group of proteins called copper chaperones. One of these chaperones in yeast is Atx1/13/, a small molecular weight protein which contains a single repeat of the MXCXXC copper-binding motif present in the Wilson and Menkes proteins (each of which contains six repeats of this motif /14/) and functions to deliver copper to the secretory pathway for biosynthesis of Fet3p, a multicopper oxidase homologous to ceruloplasmin, required for high-affinity iron uptake in yeast $/ 15 /$. This MXCXXC motif is also found in the copper chaperone (CCS) for superoxide dismutase I (SOD1) /16/, bacterial copper chaperone CopZ /17/, and in a variety of bacterial metal-transport proteins, including ZntA /18/, CopA /19/, the $\mathrm{Hg}$ (II)-resistance protein MerP and other proteins involved in resistance to $\mathrm{Cd}(\mathrm{II})$ and $\mathrm{Pb}$ (II) $/ 14,20 /$. Atx 1 interacts specifically with the yeast homologue of the Menkes and Wilson disease proteins, Ccc2p, and transfers copper to the $\mathrm{N}$-terminal cytosolic domain of $\mathrm{Ccc} 2 \mathrm{p}$, which contains two repeats of metal binding motif $/ 21,22 /$.

ATOX1 (or HAH1) has been identified as a human homologue of Atx1/23/. This protein has been shown to complement functionally atx $1 \Delta$ mutant strains in yeast, suggesting that ATOX1 plays a role in copper homeostasis in mammalian cells. Recently, similar proteins have been identified in rats $/ 24 /$, dogs $/ 25 /$, sheep $126 /$ as well as in mice $/ 27 /$. Both the Menkes and Wilson disease proteins are thought to acquire copper via ATOX1 $123,28 /$. It has been shown that ATOX1 interacts with Menkes and Wilson proteins in a copper dependent fashion $129,30 /$; however, the molecular events involved in copper transfer remain poorly understood. 
$\mathrm{X}$-ray absorption spectroscopic studies indicate that Menkes and Wilson proteins bind $\mathrm{Cu}$ (I) as twocoordinate via two Cys residues in the MXCXXC motif $/ 31,32 /$, whereas a third ligand, probably an exogenous thiol, is observed in Atx1/21/. A high resolution X-ray structure of $\mathrm{Hg}$ (II)-Atx1 reveals that the mercury is coordinated in a bidentate fashion from two cysteine sulfurs with a S- $\mathrm{Hg}$ bond angle of $167^{\circ} / 33 /$. The NMR structures of apo- and copper bound Atx 1 have also been reported /34/. In both cases, the metal bound Atx 1 exists as monomer. The Atx 1 metallochaperone $/ 33 /$, the fourth metal binding domain of Menkes protein $/ 35 /$, the bacterial copper binding protein CopZ in E. hirae $/ 36 /$, and B. subtilis $/ 37 /$, as well as the bacterial periplasmic protein MerP /38/ all adopt a $\beta \alpha \beta \beta \alpha \beta$ structural fold and exhibit one metal bound per molecule of protein. X-ray crystal structures of $\mathrm{Hg}(\mathrm{II}), \mathrm{Cd}(\mathrm{II})$ and $\mathrm{Cu}(\mathrm{I})$-bound form of ATOX1 also exhibit $\beta \alpha \beta \beta \alpha \beta$ fold but, unlike the aforementioned proteins, two adjacent molecules of ATOX1 are linked by a metal ion /39/. In Cd(II)-ATOX1, the Cd(II) ion is coordinated in a tetrahedral fashion by four Cys residues, similar to those observed in the structure of $\mathrm{Cd}(\mathrm{II}) 5 \mathrm{Zn}(\mathrm{II}) 2$ form of rat metallothionein. $\mathrm{In} \mathrm{Cu}(\mathrm{I})-\mathrm{ATOX} 1$ and $\mathrm{Hg}(\mathrm{II})-\mathrm{ATOX} 1$, the metal binding site exhibits distorted tetrahedral geometry. Structural studies of ATOX1 suggest the molecular concept of how metal ion transfer between MXCXXC containing domains takes place. The two MXCXXC motifs can dock with one another in a manner that supports the direct metal transfer mechanism proposed by Pufahl et al. $/ 21 \%$.

Despite the similarity between Atx1 and ATOX1, to date there have been no studies examining the dimerized state of metal-bound Atx1. This report presents evidence that both Atx1 and ATOX1 exist as a mixture of monomers, and dimers, and that different metals or redox states confer different conformations and oligomerization of both proteins.

\section{MATERIALS AND METHODS}

\section{Cloning of ATOX1 and Atx1}

Both ATOX1 and Atxl were expressed as fusion proteins with GST (glutathione-S-transferase) at the Nterminal portion of the molecule, using expression vector pGEX-6P-2 (Amersham-Pharmacia Biotech), according to standard protocols of molecular biology. The vector contains a "Prescission" protease (human rhinovirus $3 \mathrm{C}$ protease) cleavage site, enabling the removal of GST moiety from the cloned proteins at the final step of purification.

\section{Site directed mutageneses of ATOX1}

Mutageneses on the construct of ATOX1 in pGEX-6P-2 vector were performed by using a USE Mutageneses Kit (Amersham Pharmacia Biotech) as per protocol. Five mutants of ATOX1 with Cys residues mutated to Ser in various combination were generated, namely, C41S-ATOX1 (where $\mathrm{C}^{41}$, which is not part of metal binding motif was mutated to S), CC/SS-ATOX1 (both conserved Cys residues, $\mathrm{C}^{12}$ and $\mathrm{C}^{15}$ were mutated to $\mathrm{S}$ ), 3C/3S-ATOX1(all 3 Cys in ATOX1 were mutated), CC/SC-ATOX1 (only $\mathrm{C}^{12}$ was mutated) and $\mathrm{CC} / \mathrm{CS}-\mathrm{ATOX} 1$ (only $\mathrm{C}^{15}$ was mutated). The fidelity of the constructs was verified by automated DNA 
sequencing (DNA Sequencing Facility, Center for Applied Genomics, Hospital for Sick Children, Toronto, Canada).

\section{Expression and purification of Atx1, ATOX1 and its mutants}

All of the constructs generated as described above were used to transform E. coli BL21 (DE3) cells for protein expression. The fusion proteins were present mainly in soluble forms. The purification of GST-fusion proteins, and subsequent removal of GST, were essentially as described previously $/ 31 /$, but without urea in the buffers. The final yield of purified ATOX1 (or its mutants, as well as Atx1) was between 50-80 mg per 5 $\mathrm{L}$ of $E$. coli culture. Protein concentration was determined by BCA method (Pierce) using BSA as standard. The final protein products contained no bound metal.

\section{Size exclusion chromatography of the metal-protein complexes}

The metal protein complexes of ATOX1 or Atxl were prepared by incubating purified protein $(0.1-1$ $\mathrm{mM}$ ) in $0.5 \mathrm{ml}$ of $20 \mathrm{mM}$ MES pH 6.0, containing one molar equivalent of metal ( $\mathrm{Cu}$ (II),or $\mathrm{Ag}(\mathrm{I})$, or $\mathrm{Cd}(\mathrm{II})$ ), and 3 molar equivalent of DTT, at room temperature for $30 \mathrm{~min}$. The excess metal and reducing agent were removed by gel filtration on Bio-Gel P-10 (Bio-Rad) column (separation range $20 \mathrm{kD}-1 \mathrm{kD}$ ), with the column dimension of $1.5 \times 60 \mathrm{~cm}$. One-ml fractions were collected. The molecular sizes of the eluted metal-protein complexes were assessed by comparison with elution profiles of molecular weight standard proteins, applied to the same column.

\section{Determination of Free Thiols (EIIman's Assay)}

The free thiol group was determined in the presence and absence of $6 \mathrm{M}$ guanidine. $\mathrm{HCl}$ in $0,1 \mathrm{M}$ phosphate buffer $\mathrm{pH} 8.0$, with addition of $0.1 \mathrm{mM}$ DTNB (dithio-1,4-nitrobenzoic acid). The change in absorbance at $412 \mathrm{~nm}$ was monitored at $25^{\circ} \mathrm{C}$ and the total sulfhydryl content was calculated according to the method described by Creighton $/ 40 /$

\section{Determination of metal content in metal protein complexes}

The extent of copper, or cadmium incorporation was determined by spectrophotometry, using the metallochromic indicator 4-(2 pyridylazo)-resorcinol (PAR) to determine the amount of metal released after treatment of metal-protein complexes with sodium hypochlorite $(\mathrm{NaOCl})$, as described by Casadevall and Sarkar $/ 41 /$ with some modifications. Copper(I) content in copper bound protein was also determined by BCA reaction described by Brenner and Harris /42/. Alternatively, the $\mathrm{Cu}(\mathrm{I})$ content in the mixture was measured by the BCS competition reaction. This reagent was also used to determine $\mathrm{Cu}(\mathrm{I})$ in the presence of $\mathrm{Cu}(\mathrm{II})$ directly in titration experiments described in the following section. The appearance of a $\mathrm{Cu}(\mathrm{BCS}) 2$ 
complex was measured by monitoring the absorbance at $483 \mathrm{~nm}$, with a molar extinction coefficient of 12250 $143 /$.

\section{UV-visible spectra of metal-protein complexes}

All UV-visible spectra were recorded on a Hitachi U-3210 Spectrophotometer. Spectra of metal-protein complexes were generated by direct titration of aliquots of $\mathrm{Cu}(\mathrm{II})$ or $\mathrm{Ag}(\mathrm{I})$ solution with freshly reduced proteins (prepared by incubation of the proteins with DTT followed by gel filtration to remove excess DTT), or oxidized proteins (proteins that had been stored at $4{ }^{\circ} \mathrm{C}$ for at least 2 weeks). The spectra between wavelengths of 240-360 $\mathrm{nm}$ were recorded; the metal-complex formations were followed by measuring increases in absorbance at $254 \mathrm{~nm}$.

\section{Chemical Cross-Linking}

Cross-linking reactions were carried out in the absence and presence of metal ions, according to the manufacturer's protocol. The cross-linking agents used were DMS (dimethylsuberimidate (Pierce), spacer arm $11 \AA$ ) and EGS (ethylene glycobis(sulfosuccunimidylsuccinate (Pierce), spacer arm 16.1 $\AA$ ). Both are reactive toward amino acid containing primary amine groups such as Lys residues. The cross-linked products were analysed on SDS-PAGE. Control reactions, without cross-linkers, were performed in parallel.

\section{RESULTS AND DISCUSSION}

\section{Gel mobility patterns of different metal bound forms of ATOX1 on native and SDS gel electrophoresis.}

Figure 1A shows mobility patterns on native-PAGE of apo (untreated), reduced, and metal-bound ATOX1 in the presence of mild reducing condition (reducing agent was used at equimolar concentration of Cys-residues in the protein). The untreated apo-ATOX1 remained close to the top of the gel. In the presence of DTT, the apoprotein migrated faster toward anode and seemed to consist of more than one species. The Cu-complex of ATOXI only moved slightly faster than untreated apo, followed by $\mathrm{Ag}(\mathrm{I})-, \mathrm{Hg}(\mathrm{II})$ - and Cd(II)-ATOXI which migrated the farthest. Mobility of proteins on a native gel electrophoresis depends on various factors, including conformation, size and overall charge of the proteins. Thus the different migration patterns displayed by these metal-ATOX1 complexes suggest that these metals affect the conformation or subunit structure of the protein differently.

An attempt to identify the effects of these metals on subunit structure of ATOXI by using SDS-PAGE did not provide any conclusive information, as shown in Figures $\mathrm{BB}$ and $\mathrm{IC}$. When these complexes were separated on an SDS gel in the absence of reducing agent in gel sample buffer, the untreated apoprotein showed the presence of some dimer as well as trimer. All of the metal complexes also had the similar degree of dimerization; however, the $\mathrm{Cu}(\mathrm{I})$-ATOX 1 showed a band smearing upward from monomer toward the dimer position (Figure 1B). This band was reversible since it disappeared when SDS gel was performed 


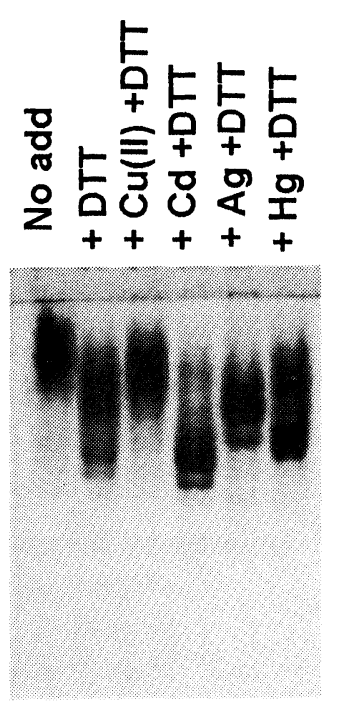

A

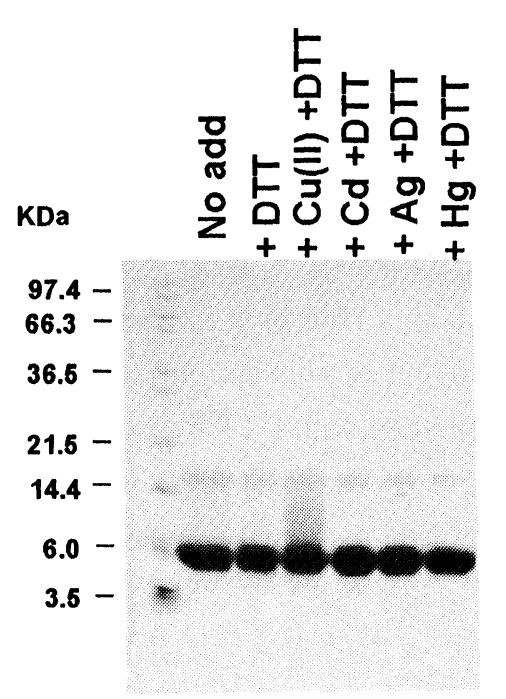

B

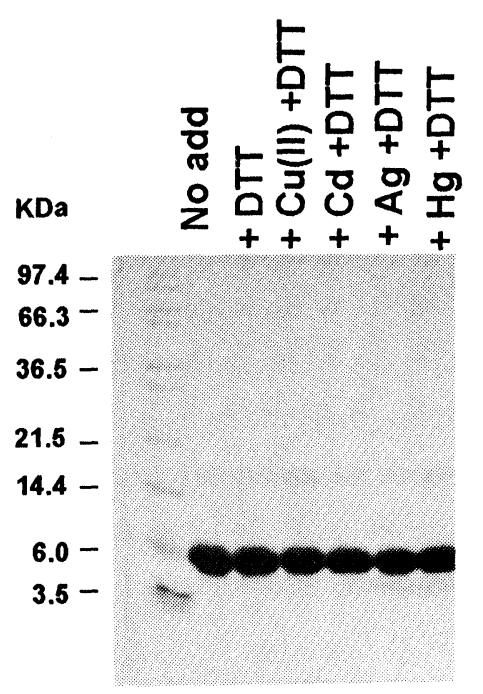

C

Fig. 1: Gel migration pattern of ATOX1 on 10\% Native-PAGE (A) and 16\% SDS-PAGE in the absence (B) or presence of $300 \mathrm{mM}$ 2-mercaptoethanol (C). Ten $\mu \mathrm{l}$ of $0.3 \mathrm{mM}$ of untreated, reduced (+DTT, 3:1 molar ratio) or 1:1 metal/protein + DTT was loaded on the gel as indicated on each lane. No add = apoprotein without DTT or metal.

using sample buffer containing excess reducing agent, as shown in Figure 1C. Results from SDS gels also indicated that some of the dimer bands observed on the gel were not formed through disulfide bonds, as the electrophoretic patterns remained even in the presence of reducing agent. Results obtained from native gel (Figure 1A) initially led us to suspect that the untreated (oxidized) apo-ATOX1 might exist as an oligomer whereas the fully reduced apo-ATOXI, as well as $\mathrm{Cd}(\mathrm{II})$-complex, is a monomer, and $\mathrm{Cu}(\mathrm{I})-\mathrm{or} \mathrm{Ag}(\mathrm{I})$ complex is a dimer. Failure to detect increased oligomerization on SDS gel might be due to the instability of dimerization by metal such that in the presence of the strong negative charge of SDS the complex was able to dissociate.

One approach to capture different stages of oligomerization of protein is to use a cross-linking reagent. Thus cross-linking reactions between metal-ATOX1 complexes and DMS, or EGS were performed, and the products were separated on SDS gel. Contrary to our suspicion that the Cd(II)-ATOXI complex may exist as a monomer, results shown in Figure $2 \mathrm{~A}$ and $2 \mathrm{~B}$ indicated that out the four metal-complexes, $\mathrm{Cd}(\mathrm{II})$ ATOX 1 could be cross-linked with EGS as a dimer. Dimerization of Cd(II)-ATOX1 could also be captured by using DMS, but to a much lesser extent. $\mathrm{Hg}(\mathrm{II})$-ATOXI complex could also form a dimer, though to a lesser extent than Cd(II)-ATOX1. Furthermore, faint bands of trimers and tetramers are also detected in the cross-linked products of metal complexes. Results obtained from these cross-linking experiments implied that $\mathrm{Cd}(\mathrm{II})$ binding to ATOXI altered the conformation on the protein so that Lys residues from each subunit became close enough to facilitate cross-linking reactions. This result also helps explain the behavior of migration of $\mathrm{Cd}(\mathrm{II})-\mathrm{ATOX} 1$ complex on native-PAGE. On native-PAGE, protein containing more exposed basic residues migrates slower toward cathode. Binding of $\mathrm{Cd}(\mathrm{II})$ to ATOXI may change conformation of the 


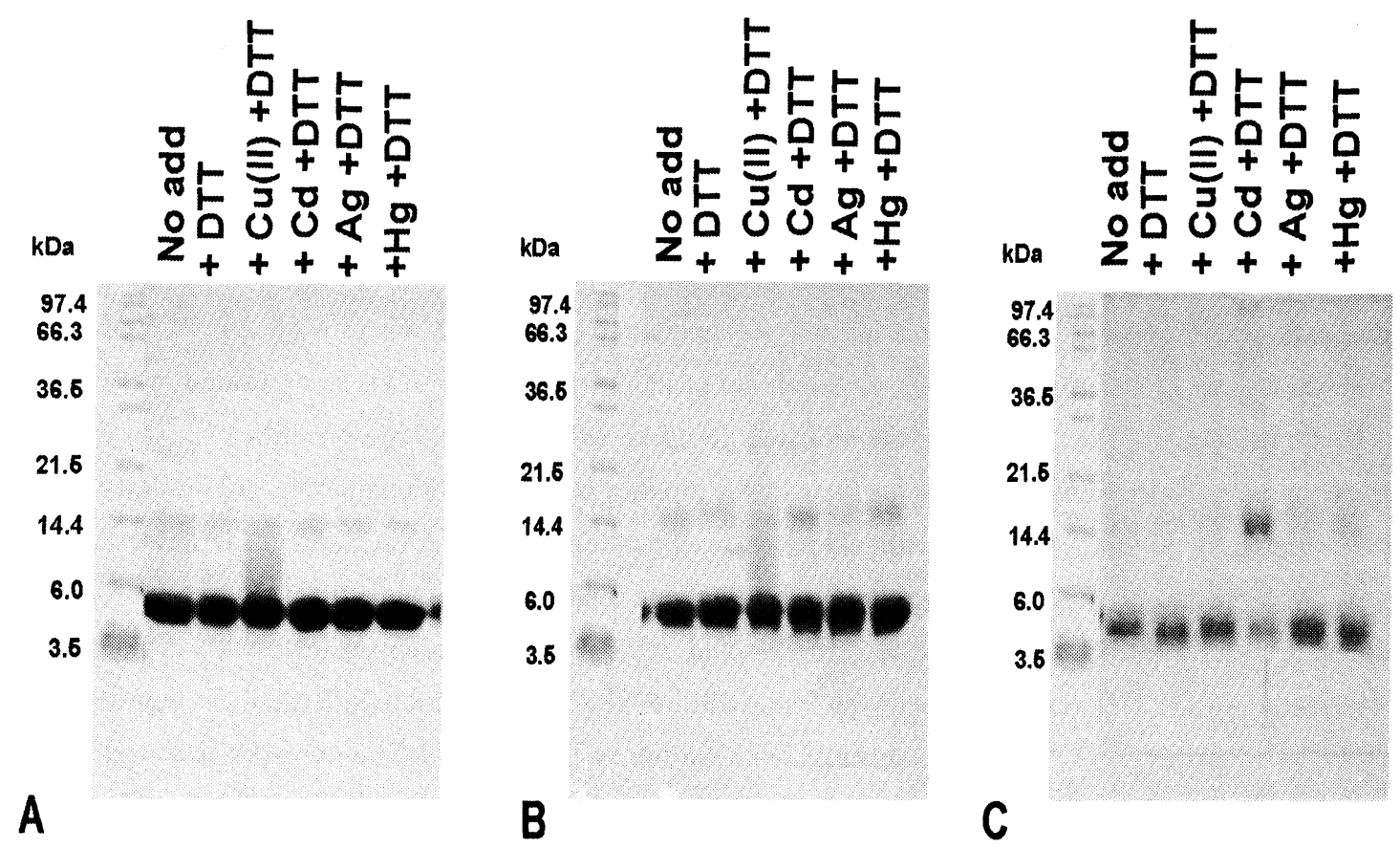

Fig. 2: SDS-PAGE of crosslinked products of ATOX1 with DMS or EGS in the absence and presence of metals + DTT. Cross-linking reactions were performed as described in the Materials and Methods section. Ten $\mu \mathrm{l}$ of cross-linked products were loaded on the gel as indicated on each lane. A, without cross-linker; B, Cross-linked with DMS; C, cross-linked with EGS. No add = apoprotein without DTT or metal.

protein so that some Lys or Arg residues are shielded or brought inward and results in decrease of overall basic charge on the surface, hence the faster migration toward cathode as compared to apo-protein. The fact that more dimer was obtained when EGS was used, as compared to DMS, indicated that the nearest distance between the Lys residues from each subunit must be slightly more than $11 \AA$, and up to at least $16 \AA$. Although the results proved that $\mathrm{Cd}(\mathrm{II})-\mathrm{ATOX} 1$ and, to some extent, $\mathrm{Hg}(\mathrm{II})-\mathrm{ATOX} 1$ complexes existed as dimers, it did not exclude the possibility that the other metal-complexes were also dimers. Specifically, apoATOX1, as well as other metal-ATOX1 proteins, may exist as dimers but have different conformations from that of Cd(II)-ATOX1 in such a way that the Lys residues from each subunit are too far apart to be crosslinked. An X-ray crystallographic study of metal-ATOX1 complexes showed that $\mathrm{Cd}$ (II) ligated to ATOX1 in a perfect tetrahedral configuration by sharing 4 Cys residues between two subunits /39/. Our results confirmed that $\mathrm{Cd}(\mathrm{II})-\mathrm{ATOX} 1$ exists as a dimer. Regarding $\mathrm{Cu}(\mathrm{I})$ and $\mathrm{Hg}(\mathrm{II})$ bindings, the results from Wernimont et al /39/ showed that these two metals could also ligate ATOX1 as a dimer through a distorted tetrahedral configuration. With respect to $\mathrm{Cu}(\mathrm{I})$-ATOXI, according to their proposed mechanism for metal transfer between subunits; at equilibrium there would be a mixture of the copper-bound forms as a monomer (when $\mathrm{Cu}(\mathrm{I})$ bound digonally between two essential Cys residues on the same subunit), and as a dimer (when $\mathrm{Cu}$ bound 3 or $4 \mathrm{Cys}$ residues trigonally or tetrahedrally between two subunits). The reason why we could not detect more dimer form of $\mathrm{Cu}(\mathrm{I})$-ATOXI than that of apo-protein by cross-linking reaction might be explained by the lack of stability of $\mathrm{Cu}(\mathrm{I})$-ATOXI dimer in solution. 


\section{Characterization of metal-complexes with ATOX1 mutants and with yeast Atx1}

Unlike ATOX1, the NMR, and X-ray crystallographic studies of Atx1 showed that the yeast protein formed complexes with $\mathrm{Cu}(\mathrm{I})$ and $\mathrm{Hg}(\mathrm{II})$ as monomer. In general, Atx 1 and ATOX 1 are very similar except that Atx 1 is five amino acids longer, and there are only two Cys residues in Atx 1 while ATOX1 has three residues. Given the possibility that the extra Cys residue $\left(\mathrm{C}^{41}\right)$ in ATOX1 plays a role in dimerization, we mutated this Cys residue to Ser. In addition, we generated four other mutants of ATOX1, which have conserved Cys residues, mutated to Ser, either singly or in various combinations as described in the Materials and Methods section. The first four mutants listed could be expressed in large quantities similar to the wild type. They were further characterized for their metal binding capability by comparing gel mobility on native gel as criteria for binding. However, for unknown reasons, cells bearing CC/CS-ATOX1 plasmid could not express the protein. Results shown in Figure 3 indicate that the three mutants lacking one or both of conserved Cys residues, namely CC/SC-, CC/SS- and 3C/3S-ATOX1, behaved differently from wild type. The presence of DTT alone or together with metal did not alter gel migration patterns from that of untreated apo-proteins. However, C41S-ATOX1 behaved in a similar fashion to wild type in response to reduction and to the presence of metals. Cross-linking experiments also showed dimerization of C41S-ATOX 1 in the presence of $\mathrm{Cd}(\mathrm{II})$, similar to what was observed with the wild type protein (data not shown). Since this mutant was generated to imitate Atx 1, this observation implied that Atx 1 should bind to various metals and behave in the same fashion as ATOX1 as well.

To prove this point, the yeast Atxl was cloned, expressed, purified. and its metal-complexes were characterized. As expected, Atxl behaved identically to ATOX1 in all aspects (Figure 4). Its tendency to

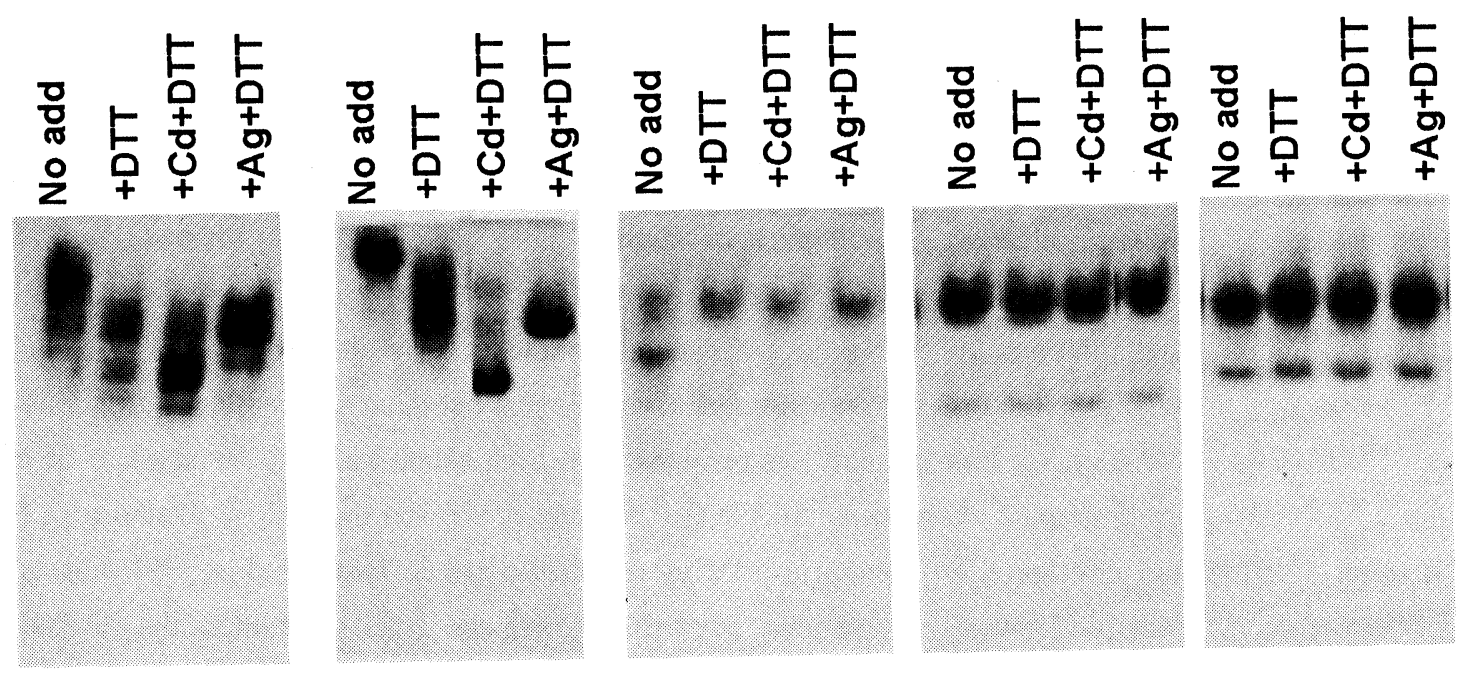

\section{Wild type C41S CC/SC CC/SS 3C/3S}

Fig. 3: Comparison of migration pattern on Native-PAGE of Wild-type and various mutants of ATOX1 with and without metals. $\mathrm{C} 41 \mathrm{~S}$, non-conserved Cys $\left(\mathrm{C}^{41}\right)$ was mutated; CC/SS, both of conserved Cys $\left(\mathrm{C}^{12}\right.$ and $\left.\mathrm{C}^{15}\right)$ were mutated; $3 \mathrm{C} / 3 \mathrm{~S}$, all 3 Cys residues were mutated; $\mathrm{CC} / \mathrm{SC}$, only one of conserved Cys $\left(\mathrm{C}^{12}\right)$ was mutated. No add = apoprotein without DTT or metal. 


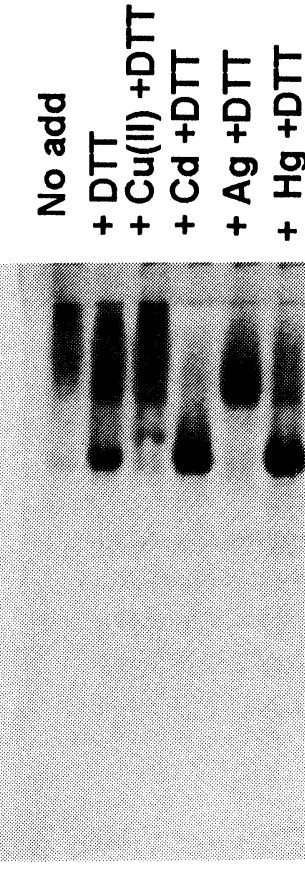

A

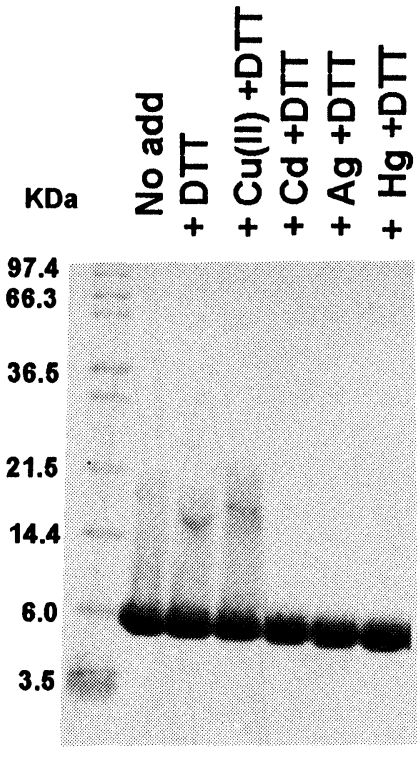

B

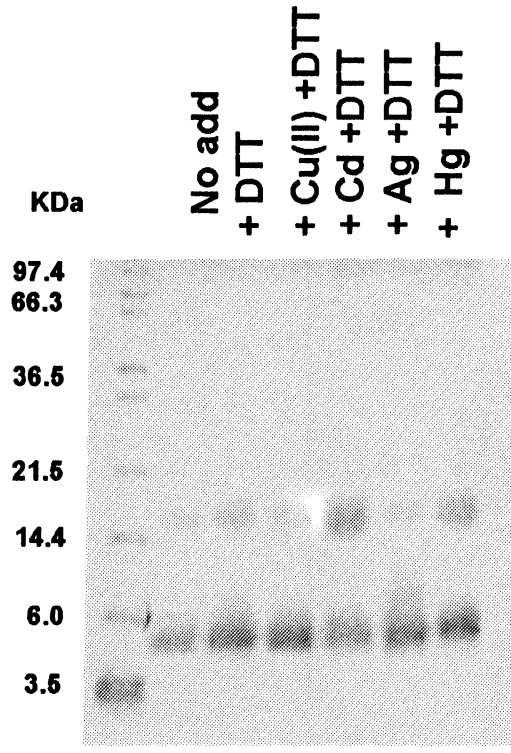

C

Fig. 4: Characterization of apo and metal-Atx 1 complexes by gel electrophoresis. A, 10\% Native-PAGE; B, 16\% SDS-PAGE without 2-mercaptoethanol; C, 16\% SDS-PAGE (without 2-mercaptoethanol) of cross-linked product of Atx 1 and EGS in the presence of metals. No add = apoprotein without DTT or metal.

dimerize in the presence of both $\mathrm{Cd}(\mathrm{II})$ as well as $\mathrm{Hg}(\mathrm{II})$ (Figure $4 \mathrm{C}$ ) is different from the observation from crystal structure of $\mathrm{Hg}$ (II)-Atx I which found the metal complex to be a monomer $/ 33 /$. From these findings, it is apparent that ATOXI and Atxl bind metals in similar manners. Based on the cross-linking experiments there is no question that in the presence of $\mathrm{Cd}(\mathrm{II})$ and $\mathrm{Hg}(\mathrm{II})$ both proteins exist as dimers. However, whether $\mathrm{Cu}(\mathrm{I})-, \mathrm{Ag}(\mathrm{I})-$ or apoprotein exists as monomer or dimer remains unclear.

\section{Size exclusion chromatography of ATOX1, Atx1 and their metal-complexes}

ATOX1, C41S-ATOX1, and Atx1, under various conditions such as untreated (oxidized apoprotein), reduced apoprotein and $\mathrm{Cu}(\mathrm{I})-, \mathrm{Ag}(\mathrm{I})-$, or $\mathrm{Cd}$-complex., were characterized on a Bio-Gel P-10 column. The concentration of proteins used was $0.3,0.5$ and $0.3 \mathrm{mM}$ for ATOX1, C41S-ATOX1 and Atx 1 respectively. The concentration of metals and DTT used was at 1:1 and 3:1 molar equivalent of protein, respectively. The elution profiles of these complexes are presented in Figure 5, which shows profiles of the apoprotein and metal-complexes of Atxl as an example. In general, the elution profiles of the three proteins are similar in many aspects. The oxidized apoproteins were eluted with a peak at fraction $39-40$ (fraction size of $1 \mathrm{ml}$ ). $\mathrm{Cu}(\mathrm{I})$ - or $\mathrm{Ag}(\mathrm{I})$-complex was also eluted off at a similar location. However, the reduced apoproteins as well 


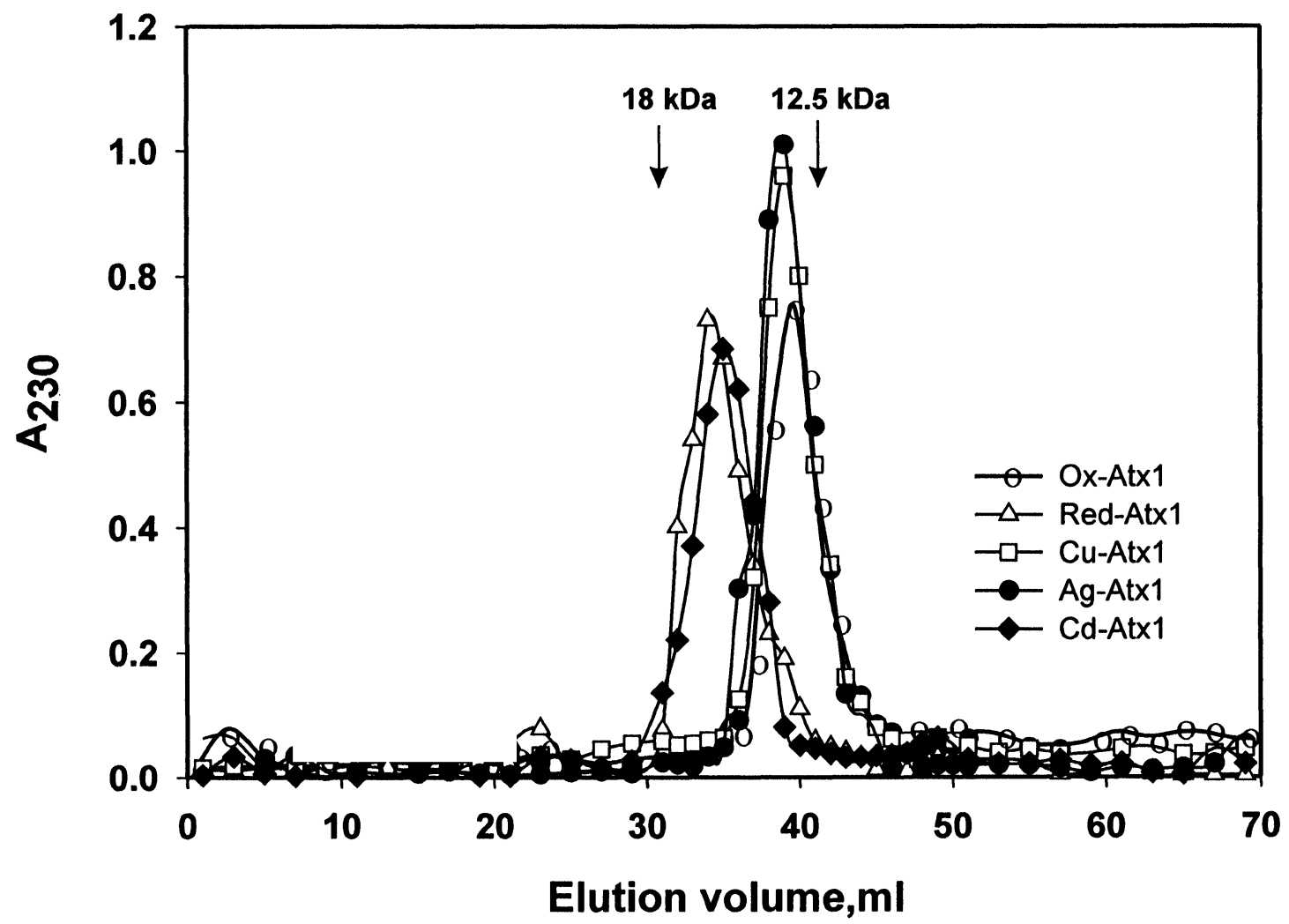

Fig. 5: Size Exclusion chromatography of Atx1. $0.5 \mathrm{ml}$ of $0.3 \mathrm{mM}$ samples of untreated apo-Atx1 (oxidized), or reduced-Atx 1 (apoprotein+DTT), or metal-Atx 1 complexes (apoprotein +metals +DTT) were loaded onto a Bio-Gel P-10 column $(1.5 \times 60 \mathrm{~cm})$. One-ml fractions were collected. Metal and DTT were added at 1:1 and 3:1 molar ratio respectively relative to protein concentration. $\mathrm{V}_{0}$ and $\mathrm{V}_{\mathrm{t}}$ of the column are at fraction 28 and 68 respectively. The elusion positions of myoglobin $(18 \mathrm{kDa})$ and cytochrome $\mathrm{C}(12.5 \mathrm{kDa})$ are marked by the arrows.

as $\mathrm{Cd}$ (II)-complex were eluted off earlier with a peak at fraction 34-35. When compared with elution profiles of standard molecular weight proteins; myoglobin $(18 \mathrm{kDa})$ and cytochrome $\mathrm{C}(12.5 \mathrm{kDa})$; the oxidized apoprotein and $\mathrm{Cu}(\mathrm{I})$-or $\mathrm{Ag}(\mathrm{l})$-complex have a molecular weight slightly larger than $12.5 \mathrm{kDa}$ whereas the reduced apoprotein and $\mathrm{Cd}(\mathrm{II})$-complex are slightly smaller than $18 \mathrm{kDa}$ but larger than oxidized apoprotein and $\mathrm{Cu}(\mathrm{I})$ - or $\mathrm{Ag}(\mathrm{I})$-complex. The molecular weights of ATOX1 and Atx1 subunit are 7.813 $\mathrm{kDa}$ and 8.518 $\mathrm{kDa}$ respectively. Thus it is likely that the reduced-apoprotein and the $\mathrm{Cd}(\mathrm{II})$-complex are dimers. It was surprising that the reduced apoprotein emerged as a dimer. Obviously dimerization involved hydrophobic interaction or some form of interaction other than disulfide formation. As for the oxidized apoprotein, $\mathrm{Cu}(\mathrm{I})-$ or $\mathrm{Ag}(\mathrm{I})$-complex, their elution profiles fit neither as a monomer nor a dimer. One possible explanation is that the peak may consist of the mixture of monomer and dimer. When the $\mathrm{Cu}(\mathrm{I})$ and $\mathrm{Cd}(\mathrm{II})$ content in the peak fraction of protein complexes was determined, there was only about 0.5-0.6 mol of $\mathrm{Cu}(\mathrm{I})$ detected per mol of protein, but $1 \mathrm{~mol}$ of $\mathrm{Cd}(\mathrm{II})$ was found per mol of protein. If the $\mathrm{Cu}(\mathrm{I})$ and $\mathrm{Cd}(\mathrm{II})$-complexes are formed with ATOXI or Atxl by sharing - $\mathrm{SH}$ groups between two subunits, then the expected amount of metal 
incorporated should be $0.5 \mathrm{~mol} / \mathrm{mol}$ protein. $\mathrm{Cu}(\mathrm{I})$ content obtained from $\mathrm{Cu}(\mathrm{I})$-Atx 1 peak seems to fit this assumption. At equilibrium there may be a mixture of $\mathrm{Cu}(\mathrm{I})$-Atxl dimers where two subunits share one bound $\mathrm{Cu}(\mathrm{I})$, some monomers with one mol of $\mathrm{Cu}(\mathrm{I})$ bound per subunit via digonal coordination, as well as some metal free subunits. As for Cd(II)-Atxl, although the physical evidence strongly suggests that the protein exists as a dimer, the 1:1 ratio of metal:protein does not support two subunits sharing one $\mathrm{Cd}(\mathrm{II})$ as seen in X-ray crystal structure /39/. Based on our results, the plausible explanation would be either Cd(II) bound to Atx1 as 1:1 ratio via digonal coordinate or the protein dimers share two mol of $\mathrm{Cd}(\mathrm{II})$ in a dimetal cluster

When ATOX1 was incubated with 2-fold excess of $\mathrm{Cu}(\mathrm{II})$ plus DTT and at higher protein concentration $(1 \mathrm{mM})$, the elution profile of $\mathrm{Cu}(\mathrm{I})$-complex emerged as two well-separated peaks (Figure 6). The first peak came off at the void volume and contained some precipitation; the second peak was at fraction 35-36, which is the range of dimer/monomer mixture. The first peak contained some aggregated $\mathrm{Cu}(\mathrm{I})$-bound protein, which formed a yellowish-green precipitate after centrifugation. The $\mathrm{Cu}(\mathrm{I})$ content in the soluble part of this peak was about $2 \mathrm{~mol}$ per mol of protein, whereas the $\mathrm{Cu}(\mathrm{I})$ content in the second peak was only 0.5 per mol. The precipitation of $\mathrm{Cu}(\mathrm{I})$-protein complex, when ATOX1 was used at high concentration and in the presence of 2 times excess copper, has been consistently observed in our laboratory when the dialysis method was used to remove excess copper, even under inert atmosphere of argon gas. On all occasions, although the solution of the protein-Cu mixture was clear during the incubation period ( $30 \mathrm{~min})$, a significant amount of

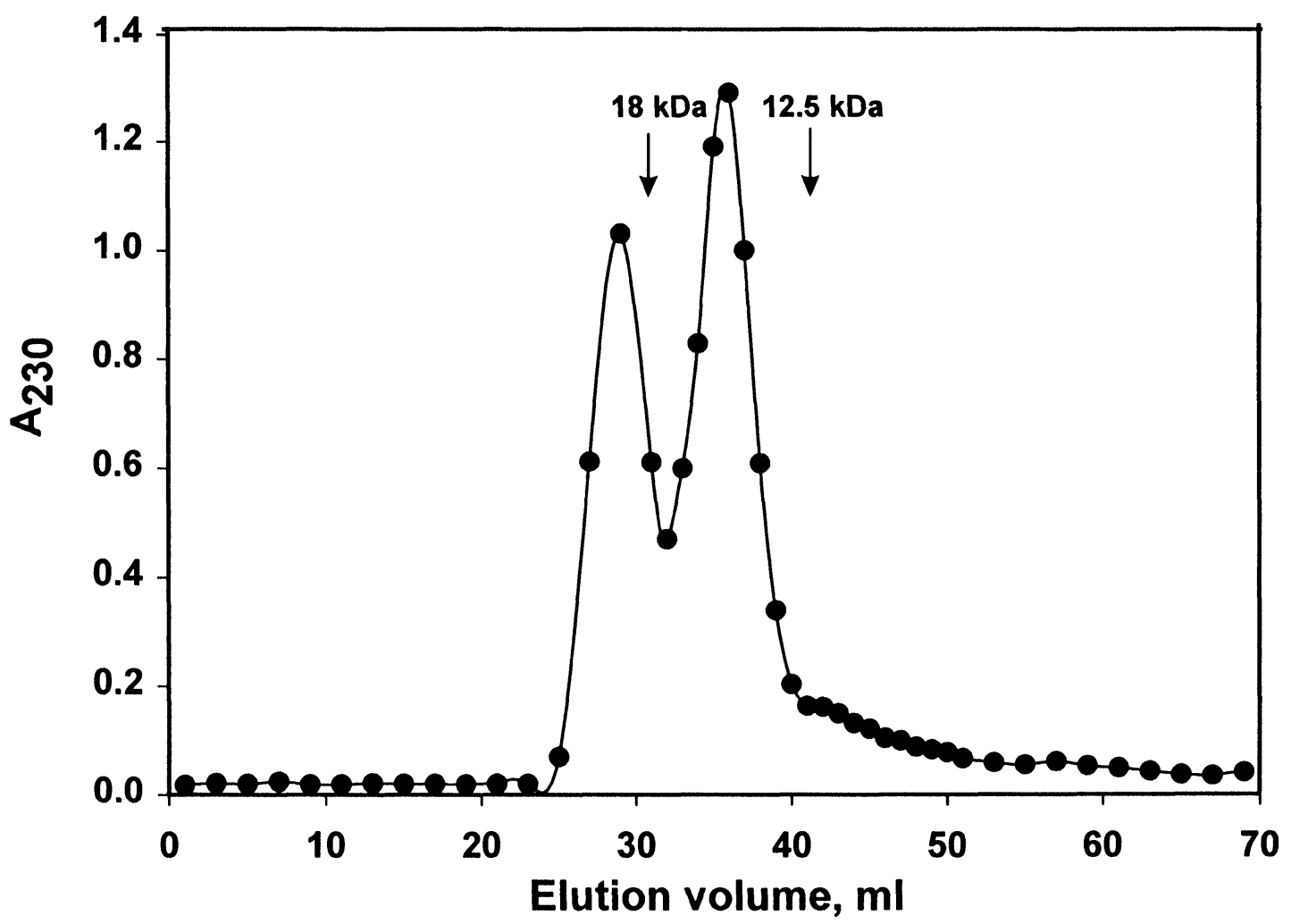

Fig. 6: Size Exclusion chromatography of $\mathrm{Cu}(\mathrm{I})-\mathrm{ATOX} 1.0 .5 \mathrm{ml}$ of $1 \mathrm{mM}$ Atox $1+2 \mathrm{mM} \mathrm{Cu}(\mathrm{II})+3 \mathrm{mM}$ DTT was loaded onto a Bio-Gel P-10 column. All conditions are the same as in Figure 5 
protein precipitated during the dialysis period, and the precipitate always had a yellowish-green color. Initially we suspected that the precipitation might be due to the presence of excess $\mathrm{Cu}(\mathrm{II})$ adversely affecting the protein, because dialysis did not remove it fast enough to prevent this consequence. In contrast, in the gel filtration experiments, we expected that the protein complex would be separated from the excess $\mathrm{Cu}(\mathrm{II})$ faster than by dialysis and precipitation would not take place. It should be pointed out that at the time of loading to the column, the protein mixture did not show any sign of precipitation; nevertheless, the first peak of $\mathrm{Cu}(\mathrm{I})$ ATOX1 emerged as a mixture of insoluble and soluble oligomers, which also incorporated more $\mathrm{Cu}(\mathrm{I})$ than the complex in the second peak. These findings suggest that polymerization of $\mathrm{Cu}(\mathrm{I})-\mathrm{ATOX} 1$ depends on protein as well as copper concentrations. A similar observation on $\mathrm{Cu}(\mathrm{I})$-CopZ has also been reported /36/: that $\mathrm{Cu}(\mathrm{I})$-protein complex aggregated at protein concentration higher than $0.7 \mathrm{mM}$. The oligomeric state of $\mathrm{Cu}(\mathrm{I})$-ATOX 1 contains at least $2 \mathrm{~mol}$ of $\mathrm{Cu}(\mathrm{I})$ per mol of protein. The copper chaperone protein Cox 17, the mitochondrial metallochaperone, has been reported to exist as a dimer/tetramer of polycopper complex, with each subunit binding $3 \mathrm{~mol}$ of $\mathrm{Cu}(\mathrm{I})$ as a trinuclear cluster /44/. Copper was also reported to enhance homodimerization of yeast CCS, a copper chaperone for SOD1 (45). Domains I and III of hCCS, a human homologue, were found to interact with each other via cysteine-bridged dicopper cluster, with up to $3.5 \mathrm{~mol}$ of $\mathrm{Cu}(\mathrm{I})$ bound per mol $/ 46 /$. How multiple $\mathrm{Cu}(\mathrm{I})$ atoms bind to ATOX1 oligomers is unclear and further investigation is currently underway.

\section{UV-visible spectral characteristics of metal-protein complexes of Atx1 and ATOX1}

The peak fraction of metal-protein complexes of Atx 1, obtained from gel filtration experiments shown in Figure 5, were scanned between the wavelengths of $240-360 \mathrm{~nm}$. Other than the protein peak at $276 \mathrm{~nm}$, all metal-bound proteins displayed an increase in absorbance at $254 \mathrm{~nm}$, as compared to apoprotein, but with different intensity depending on the metal used. $\mathrm{Ag}(\mathrm{I})$-complex was the highest, followed by $\mathrm{Cu}(\mathrm{I})$-complex, then Cd(II)-complex, which had the weakest absorption at this wavelength (Figure 7). The scans of ATOX1 or C4IS-ATOX1 complexed with metals also showed similar results (data not shown). The absorbance at $254 \mathrm{~nm}$ is probably due to the metal thiolate bond of metal protein complex.

Next, a titration experiment was attempted by following the increase in the absorbance at $254 \mathrm{~nm}$ after addition of $\mathrm{Cu}(\mathrm{II})$ solution to the freshly reduced ATOX1. Figure 8A shows typical results of titration between reduced ATOX1 with increasing concentration of $\mathrm{Cu}(\mathrm{II})$, from 0.1 to 6 molar ratios with respect to protein. As can be seen, the absorbance at $254 \mathrm{~nm}$ increased with increasing ratio of $\mathrm{Cu}(\mathrm{II})$ and slowly leveled off after 2:1 molar ratio of $\mathrm{Cu}(\mathrm{II})$ to protein was added. After ATOX1 was titrated with 6 molar excess of $\mathrm{Cu}(\mathrm{II})$, there was only a total of $1 \mathrm{~mol}$ of $\mathrm{Cu}(\mathrm{I})$ incorporated per mol of protein, as determined by $\mathrm{BCS}$ reaction with the metal-protein mixture. $\mathrm{BCS}$ reacts specifically with $\mathrm{Cu}(\mathrm{I})$ and can be used to assay $\mathrm{Cu}(\mathrm{I})$ in the presence of excess $\mathrm{Cu}(\mathrm{II})$ (43) The $\mathrm{Cu}(\mathrm{I})$-ATOXI complex (or CuATOXI) was relatively stable for at least 5 days. It should be pointed out also that these experiments were performed under normal laboratory conditions without any extra precaution of maintaining anaerobic environment. Under these conditions, there was no evidence of precipitation when excess $\mathrm{Cu}(\mathrm{II})$ was used. These findings contrasted the result obtained when the protein was used at $1 \mathrm{mM}$ and with $2 \mathrm{x} \mathrm{Cu}(\mathrm{II})$, which resulted in two species of $\mathrm{Cu}(\mathrm{I})$-complexes, one more aggregated containing $2 \mathrm{~mol} \mathrm{of} \mathrm{Cu}(\mathrm{I}) / \mathrm{mol}$ protein, the other soluble but 


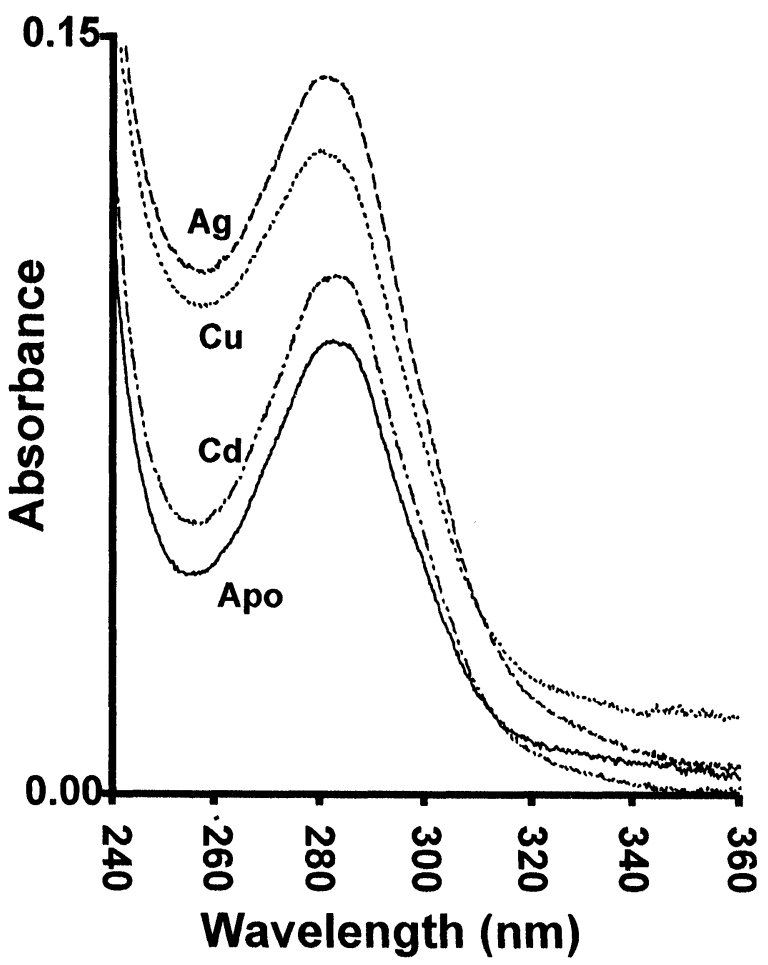

Fig. 7: UV-visible Spectra of metal-Atxl complexes. Peak fractions (15 $\mu \mathrm{M}$, each) from reduced apo-Atx 1, $\mathrm{Cd}(\mathrm{II})-\mathrm{Atx} 1, \mathrm{Cu}(\mathrm{I})-\mathrm{Atx} 1$ and $\mathrm{Ag}(\mathrm{I})-\mathrm{Atx} 1$ as shown in Figure 5 were scanned between 240-360 nm

containing only $0.5 \mathrm{~mol}$ of $\mathrm{Cu}(\mathrm{I})$ (see Figure 6). From titration experiments, due to low protein concentration $(15 \mu \mathrm{M})$, it was not possible to identify whether there was one or two species of complexes in the solution. The presence of $\mathrm{Cu}(\mathrm{I})$ at $1 \mathrm{~mol} / \mathrm{mol}$ may represent the homogeneous species of $\mathrm{Cu}(\mathrm{l})$ bound in digonal geometry or it may consist of the mixture of dicopper and half-copper species as observed in Figure 6.

Titration of reduced ATOX1 with $\mathrm{Ag}(\mathrm{I})$ also generated a pattern of incremental absorbance at $254 \mathrm{~nm}$ that was almost identical to that of $\mathrm{Cu}$ (II) titration (Figure $8 \mathrm{~B}$ ). The increase of absorbance generated by $\mathrm{Cu}(\mathrm{II})$ or $\mathrm{Ag}(\mathrm{I})$ titration was reversible after the $\mathrm{pH}$ of the mixture was decreased below $\mathrm{pH} 2$. Titration with $\mathrm{Cd}(\mathrm{II})$ produced a very small increase in absorbance at $254 \mathrm{~nm}$ (data not shown).

When oxidized ATOX1 was titrated with $\mathrm{Cu}(\mathrm{II})$, surprisingly, there was also an increase in absorbance at $254 \mathrm{~nm}$, which reached saturation with excess $\mathrm{Cu}$ (II) (Figure 8C). However, unlike the reduced protein, the oxidized ATOX1 did not have any interaction with $\operatorname{Ag}(\mathrm{I})$ since there was no increase in absorbance at 254 $\mathrm{nm}$ with addition of $\mathrm{Ag}(\mathrm{I})$ (Figure 8D). There was also a pronounced difference in absorbance of $\mathrm{Cu}$-thiolate products of oxidized and reduced ATOX1 at wavelength $300 \mathrm{~nm}$ (see Figures $8 \mathrm{~A}$ and $8 \mathrm{C}$ ). There was only 0.2-0.25 mol of $\mathrm{Cu}(\mathrm{I})$ formed per mol of protein, in the mixture of oxidized ATOX 1 and 6 molar excess of $\mathrm{Cu}(\mathrm{II})$, as opposed to 1:1 mol ratio when reduced protein was used. One possible argument for finding some $\mathrm{Cu}(\mathrm{I})$-complex with oxidized protein is that there was still a substantial residual amount of reduced form in the mixture of "oxidized protein"; however, the lack of response to $\mathrm{Ag}(\mathrm{I})$ titration does not support this explanation. When oxidized ATOX1 $(0.89 \mathrm{mM})$ was incubated with 3 molar excess of $\mathrm{Cu}($ II) and then separated on a gel filtration column, aggregation of protein was not observed, as was the case when ATOX1 

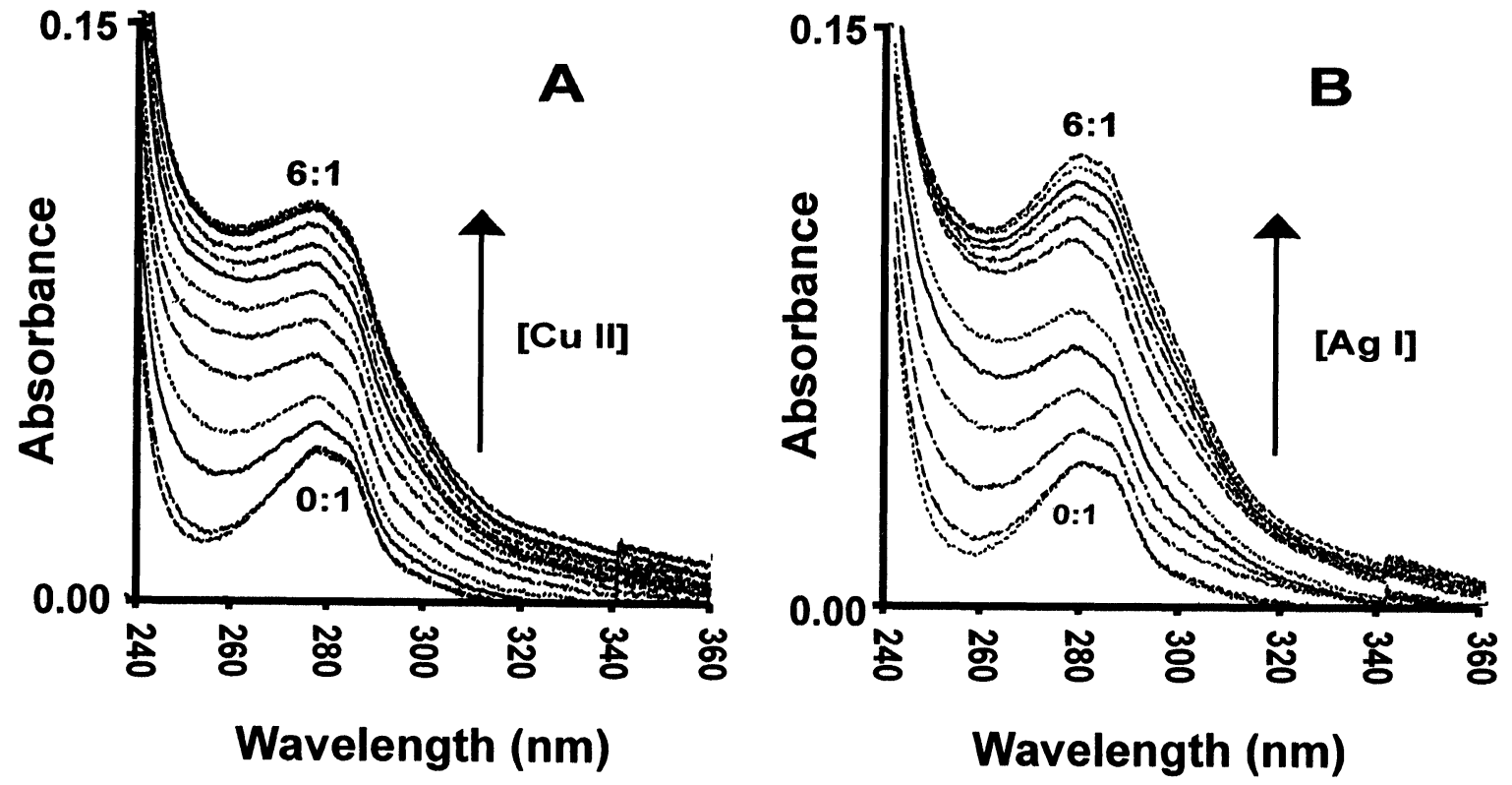

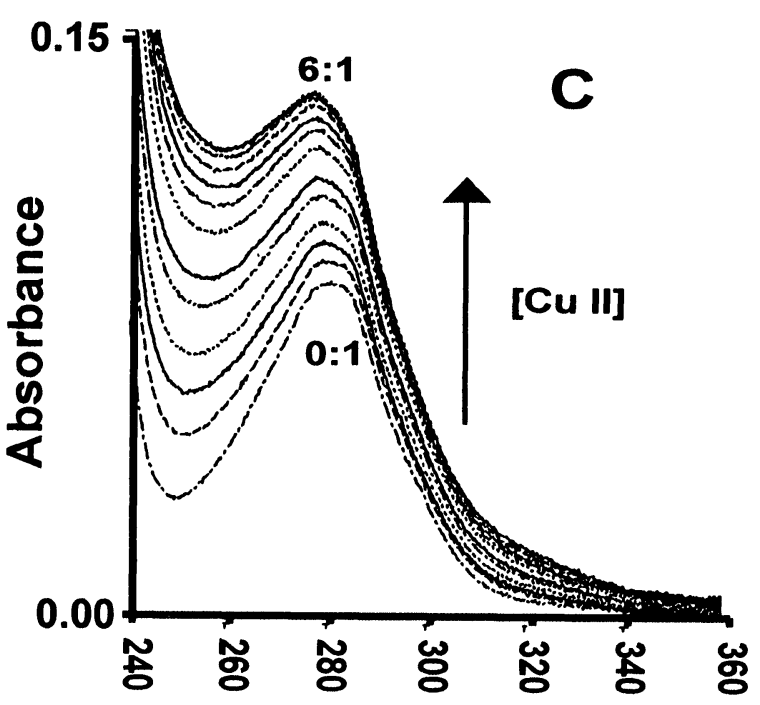

Wavelength (nm)

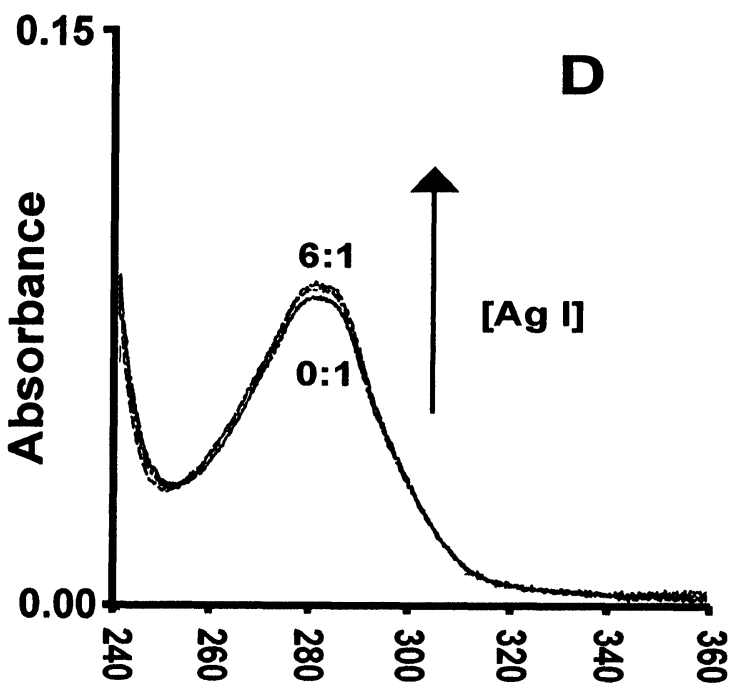

Wavelength (nm)

Fig. 8: UV-visible Spectra of the titration of Reduced and Oxidized ATOX1 with Cu(II) and Ag(I). $15 \mu \mathrm{M}$ of oxidized or freshly reduced ATOXI was titrated with small increment of $\mathrm{CuSO}_{4}$ or $\mathrm{AgNO}_{3}$. Metals were added at $0,0.1,0.2,0.4,0.6,0.8,1.0,1.5,2.0,2.5,3.0,4.0,5.0$ and 6.0 molar ratio with respect to protein concentration. The arrows indicate the direction of spectra from each addition. A, Reduced ATOX1 $+\mathrm{CuSO}_{4}$. B, Reduced ATOXI $+\mathrm{AgNO}_{3}$. C, Oxidized ATOXI $+\mathrm{CuSO}_{4}$. D, Oxidized ATOXI $+\mathrm{AgNO}_{3}$.

was incubated with 2:1 Cu(II) in the presence of DTT, and then separated on the column (shown in Figure 6). After treatment, the protein still emerged at the same position as untreated oxidized ATOX1. Furthermore, neither $\mathrm{Cu}(\mathrm{I})$ nor $\mathrm{Cu}(\mathrm{II})$ was detected in the protein fractions. When an aliquot from these fractions was re- 
titrated with $\mathrm{Cu}(\mathrm{II})$ and $\mathrm{Ag}(\mathrm{I})$, it produced the same results shown in Figure $8 \mathrm{C}$ and $\mathrm{D}$, with a yield of $\mathrm{Cu}(\mathrm{I})$ formation of $0.2 \mathrm{~mol}$ per mol of protein. These findings suggest that both oxidized and reduced forms of ATOX1 are able to bind $\mathrm{Cu}$ (II) and convert it to $\mathrm{Cu}(\mathrm{I})$ but the capacity for reduction of $\mathrm{Cu}(\mathrm{II})$ is much more limited in the oxidized form. Additionally, the affinity of oxidized ATOX1 for copper is much weaker, and the binding is unstable as compared to the reduced protein. The reduction of the protein and its subsequent dimerization may be a prerequisite for metal binding and its stabilization. To our knowledge, this is the first time that Atxl or ATOX1 was demonstrated to bind $\mathrm{Cu}(\mathrm{II})$ and reduce it to $\mathrm{Cu}(\mathrm{I})$ without an exogenous reducing agent being present. Previously, $\mathrm{Cu}(\mathrm{I})$-protein complexes of various copper chaperones and of the copper-binding domains of Wilson and Menkes proteins were obtained either by adding $\mathrm{Cu}(\mathrm{II})$ plus excess reducing agent $/ 21,31 / 37,47 /$, or $\mathrm{Cu}(\mathrm{I})$ plus reducing agent $/ 36,45,48 /$ to the protein solution. $\mathrm{As}$ for $\mathrm{Ag}(\mathrm{I})$, this metal could bind only to the reduced ATOX1 but not to the oxidized form, if the increase in absorbance at $254 \mathrm{~nm}$ is taken as a criterion for binding.

To clarify the differences between reduced and oxidized ATOX1 and their respective metal complexes further, these samples were subjected to native gel electrophoresis. As shown in Figure 9A, the oxidized protein consisted of two bands with equal intensity and addition of $\mathrm{Cu}(\mathrm{II}), \mathrm{Ag}(\mathrm{I})$ or $\mathrm{Cd}(\mathrm{II})$ had no effect on migration pattern of the protein. However, there were striking differences among products of metal complexes of freshly reduced protein, as shown in Figure 9B. Compared to the oxidized form, which contained two bands, the reduced protein consisted mainly of a slower migrating upper band. $\mathrm{Cu}$ (II) did not change the migration pattern from that of reduced protein alone, but the addition of an identical amount of $\mathrm{Ag}(\mathrm{I})$ resulted in a complex which migrated faster than the apoprotein. This occurred in spite of the fact that both metals produced a similar increase in absorbance at $254 \mathrm{~nm}$. Since $\mathrm{Cu}(\mathrm{I})$ and $\mathrm{Ag}(\mathrm{I})$ have identical

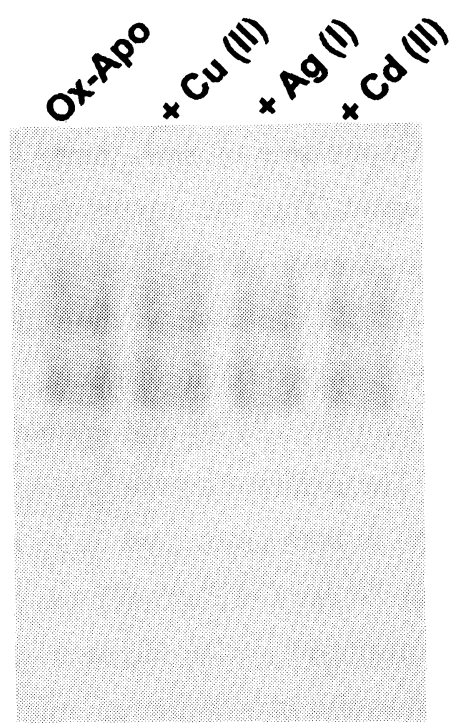

A

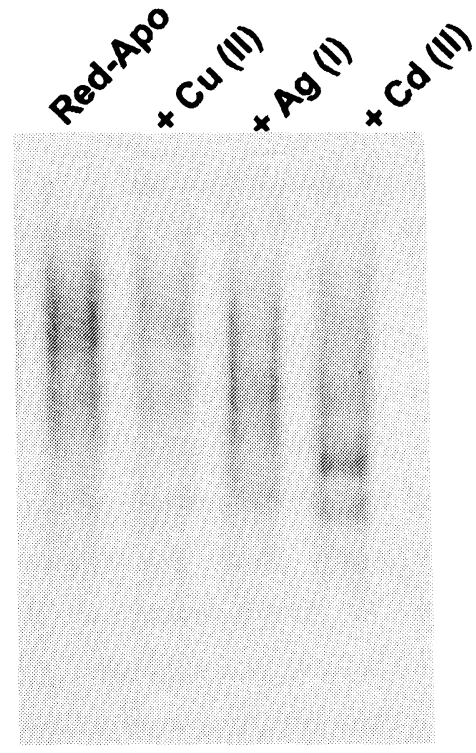

B

Fig. 9: Native-PAGE of metal complexes formed by direct addition (1:1 mol ratio) of $\mathrm{Cu}$ (II), $\mathrm{Ag}$ (I) or $\mathrm{Cd}$ (II) to oxidized, (A); or freshly reduced ATOXI, (B). 
charges, if both metals bind to the protein with the same coordination, then the overall charge effect on the complex should be the same. The difference in migration patterns on native-PAGE suggests that complexes formed by these two metals with ATOX1 are different.

$\operatorname{Ag}(\mathrm{I})$ was used as a ligating metal in an NMR study of the $4^{\text {th }} \mathrm{Cu}$-binding domain of Menkes protein $/ 35 /$; it formed a complex with the Cys residue in the MXCXXC motif of this peptide in a digonal geometry. $\mathrm{Cu}(\mathrm{I})$ and $\mathrm{Ag}(\mathrm{I})$ were assumed to coordinate this motif in a similar fashion. Radioactive silver has been used in fibroblast silver loading for diagnosis of Menkes disease /49/. Beside $\mathrm{Cu}(\mathrm{I}), \mathrm{Ag}(\mathrm{I})$ is also a substrate for a bacterial /50/, as well as a yeast /51/, P-type ATPase homologue of Wilson and Menkes protein. The $\mathrm{Cu} / \mathrm{Ag}$ ATPase, CopB, in E. hirae was found to have the same apparent $\mathrm{Km}$ for both metals implying similarity in metal binding /50/. However, the results from our study suggest that $\mathrm{Ag}(\mathrm{I})$ and $\mathrm{Cu}(\mathrm{I})$ binding to ATOX1 and Atx 1 cause different changes in conformation of the proteins.

Binding of $\mathrm{Cd}(\mathrm{II})$ to reduced Atox 1 also resulted in a complex that migrated faster than $\mathrm{Ag}(\mathrm{I})$-complex. In this experiment, the patterns of gel migration of metal complexes formed by direct addition of metals to the reduced protein in the absence of DTT are similar to those formed in the presence of DTT as shown in Figure $1 \mathrm{~A}$.

\section{CONCLUSIONS}

We have presented evidence that ATOX1 and Atx1, as expressed, purified and used in this study, are indistinguishable from each other in terms of subunit structure and metal binding properties. Both proteins show the ability to bind to various heavy metals such as $\mathrm{Cu}(\mathrm{I}), \mathrm{Ag}(\mathrm{I}), \mathrm{Cd}(\mathrm{II})$ and $\mathrm{Hg}(\mathrm{II})$. However, irrespective of whether ATOX1 or Atx1 is used, each of these metals seems to confer different effects on the conformation or oligomerization state of the protein, as demonstrated by migration patterns on native gel electrophoresis, by cross-linking reactions and by different intensity of absorbance at $254 \mathrm{~nm}$, which represent metal-thiolate charge transfer spectra. Moreover, we are able to show that ATOX1 can bind and reduce $\mathrm{Cu}(\mathrm{II})$ into $\mathrm{Cu}(\mathrm{I})$ in the absence of added reducing agent. Thus the protein indeed possesses redox activity. Previously, the $\mathrm{Cu}(\mathrm{I})$ complex of ATOX1, Atx1, or copper-binding motif of Menkes or Wilson disease protein was only demonstrated by addition of either $\mathrm{Cu}(\mathrm{I})$ solution to the reduced protein or by adding $\mathrm{Cu}(\mathrm{II})$ solution in the presence of excess reducing agent to the protein solution. In this study, freshly reduced $\mathrm{ATOX} 1$ was able to reduce $\mathrm{Cu}(\mathrm{II})$ to $\mathrm{Cu}(\mathrm{I})$ stoichiometrically to mol equivalent of the protein present irrespective of the excess amount of $\mathrm{Cu}(\mathrm{II})$ added. The oxidized protein was also able to convert $\mathrm{Cu}(\mathrm{II})$ to $\mathrm{Cu}(\mathrm{I})$ but with only about $20 \%$ efficiency, although in both cases there were similar increases in absorbance at $254 \mathrm{~nm}$ after same amount of $\mathrm{Cu}(\mathrm{II})$ was added. Unlike $\mathrm{Cu}(\mathrm{II}), \mathrm{Ag}(\mathrm{I})$ was able to bind only to the reduced form of the protein, and although Ag(I)-ATOX1 displayed similar increase in UV-visible spectra as $\mathrm{Cu}(\mathrm{I})-\mathrm{ATOX} 1$, their conformations were definitely different as shown by native gel migration patterns.

Our studies provide strong evidence that $\mathrm{Cd}(\mathrm{II})$-complex of either protein is a dimer, the $\mathrm{Hg}(\mathrm{II})$-complex is also dimeric, but $\mathrm{Cu}(\mathrm{I})$-complex is a mixture of various forms depending on the concentration of protein and the molar ratio of copper used. These findings indicate the need for cautious interpretation of structural data for the copper chaperones or their target proteins. In the past, $\mathrm{Ag}(\mathrm{I}), \mathrm{Hg}(\mathrm{II}), \mathrm{Cu}(\mathrm{I})$ or $\mathrm{Cd}(\mathrm{II})$ has been 
used in NMR or X-ray crystallographic studies of the structure of these proteins $/ 33-36,39 / . \mathrm{Ag}(\mathrm{I})$ was used as a ligating metal in NMR study of the fourth copper binding domain of Menkes protein $/ 35 /$. In the case of ATOX1, the crystal structure of $\mathrm{Cd}(\mathrm{II}), \mathrm{Hg}(\mathrm{II})$ as well as $\mathrm{Cu}(\mathrm{I})$-complex revealed the presence of dimer for all three metal complexes /39/, whereas $\mathrm{Hg}$ (II)-Atx1/33/ or $\mathrm{Cu}(\mathrm{I})$-Atx1 /34/ was found to exist as a monomer. Although $\mathrm{Ag}(\mathrm{I})$ had never been used in the studies of either ATOX1 or Atx1, from our studies presented here it is clear that $\mathrm{Ag}(\mathrm{I})$ - complex of both proteins is different from that of $\mathrm{Cu}(\mathrm{I})$-complex.

\section{ACKNOWLEDGMENT}

We thank Drs. Diane W. Cox and Valeria C. Culotta for cDNAs of ATOX1 and Atx1 respectively. We also thank Dr. Michael DiDonato for his constructive comments.

\section{REFERENCES}

1. C. D. Vulpe and S. Packman, Annu Rev Nutr 15, 293 (1995).

2. C. Vulpe, B. Levinson, S. Whitney, S. Packman, and J. Gitschier, Nat Genet 3, 7 (1993).

3. J. F. Mercer, J. Livingston, B. Hall, J. A. Paynter, C. Begy, S. Chandrasekharappa, P. Lockhart, A. Grimes, M. Bhave, D. Siemieniak, and et al., Nat Genet 3, 20 (1993).

4. P. C. Bull, G. R. Thomas, J. M. Rommens, J. R. Forbes, and D. W. Cox, Nat Genet 5, 327 (1993).

5. R. E. Tanzi, K. Petrukhin, I. Chernov, J. L. Pellequer, W. Wasco, B. Ross, D. M. Romano, E. Parano, L. Pavone, L. M. Brzustowicz, and et al., Nat Genet 5, 344 (1993).

6. Y. Yamaguchi, M. E. Heiny, M. Suzuki, and J. D. Gitlin, Proc Natl Acad Sci U S A 93, 14030 (1996).

7. M. J. Petris, J. F. Mercer, J. G. Culvenor, P. Lockhart, P. A. Gleeson, and J. Camakaris, Embo J 15, 6084 (1996).

8. H. A. Dierick, A. N. Adam, J. F. Escara-Wilke, and T. W. Glover, Hum Mol Genet 6, 409 (1997).

9. I. H. Hung, M. Suzuki, Y. Yamaguchi, D. S. Yuan, R. D. Klausner, and J. D. Gitlin, J Biol Chem 272, 21461 (1997).

10. X. L. Yang, N. Miura, Y. Kawarada, K. Terada, K. Petrukhin, T. Gilliam, and T. Sugiyama, Biochem J 326, 897 (1997).

11. B. Sarkar, Chem Rev 99, 2535 (1999).

12. D. S. Yuan, R. Stearman, A. Dancis, T. Dunn, T. Beeler, and R. D. Klausner, Proc Natl Acad Sci US A 92, 2632 (1995).

13. S. J. Lin and V. C. Culotta, Proc Natl Acad Sci U S A 92, 3784 (1995).

14. P. C. Bull and D. W. Cox, Trends Genet 10, 246 (1994).

15. S. J. Lin, R. A. Pufahl, A. Dancis, T. V. O'Halloran, and V. C. Culotta, J Biol Chem 272, 9215 (1997).

16. V. C. Culotta, L. W. Klomp, J. Strain, R. L. Casareno, B. Krems, and J. D. Gitlin, J Biol Chem 272 , 23469 (1997). 
17. P. Cobine, W. A. Wickramasinghe, M. D. Harrison, T. Weber, M. Solioz, and C. T. Dameron, FEBS Lett 445, 27 (1999).

18. C. Rensing, B. Mitra, and B. P. Rosen, Proc Natl Acad Sci U S A 94, 14326 (1997).

19. C. Rensing, B. Fan, R. Sharma, B. Mitra, and B. P. Rosen, Proc Natl Acad Sci U S A 97, 652 (2000).

20. C. Rensing, Y. Sun, B. Mitra, and B. P. Rosen, J Biol Chem 273, 32614 (1998).

21. R. A. Pufahl, C. P. Singer, K. L. Peariso, S. J. Lin, P. J. Schmidt, C. J. Fahrni, V. C. Culotta, J. E. Penner-Hahn, and T. V. O'Halloran, Science 278, 853 (1997).

22. D. L. Huffman and T. V. O'Halloran, J Biol Chem 275, 18611 (2000).

23. L. W. Klomp, S. J. Lin, D. S. Yuan, R. D. Klausner, V. C. Culotta, and J. D. Gitlin, J Biol Chem 272, 9221 (1997).

24. G. S. Naeve, A. M. Vana, J. R. Eggold, G. S. Kelner, R. Maki, E. B. Desouza, and A. C. Foster, Neuroscience 93, 1179 (1999).

25. M. S. Nanji and D. W. Cox, Genomics 62, 108 (1999).

26. P. J. Lockhart and J. F. Mercer, Biochim Biophys Acta 1490, 11 (2000).

27. I. Hamza, L. W. Klomp, R. Gaedigk, R. A. White, and J. D. Gitlin, Genomics 63, 294 (2000).

28. I. H. Hung, R. L. Casareno, G. Labesse, F. S. Mathews, and J. D. Gitlin, J Biol Chem 273, 1749 (1998).

29. D. Larin, C. Mekios, K. Das, B. Ross, A. S. Yang, and T. C. Gilliam, J Biol Chem 274, 28497 (1999).

30. I. Hamza, M. Schaefer, L. W. Klomp, and J. D. Gitlin, Proc Natl Acad Sci U S A 96, 13363 (1999).

31. M. DiDonato, H. F. Hsu, S. Narindrasorasak, L. Que, Jr., and B. Sarkar, Biochemistry 39, 1890 (2000).

32. M. Ralle, M. J. Cooper, S. Lutsenko, and N. J. Blackburn, J. Am. Chem. Soc. 120, 13525 (1998).

33. A. C. Rosenzweig, D. L. Huffman, M. Y. Hou, A. K. Wernimont, R. A. Pufahl, and T. V. O'Halloran, Structure Fold Des 7, 605 (1999).

34. F. Arnesano, L. Banci, I. Bertini, D. L. Huffman, and T. V. O'Halloran, Biochemistry 40, 1528 (2001).

35. J. Gitschier, B. Moffat, D. Reilly, W. I. Wood, and W. J. Fairbrother, Nat Struct Biol 5, 47 (1998).

36. R. Wimmer, T. Herrmann, M. Solioz, and K. Wuthrich, J Biol Chem 274, 22597 (1999).

37. L. Banci, I. Bertini, R. Del Conte, J. Markey, and F. J. Ruiz-Duenas, Biochemistry 40, 15660 (2001).

38. R. A. Steele and S. J. Opella, Biochemistry 36, 6885 (1997).

39. A. K. Wernimont, D. L. Huffman, A. L. Lamb, T. V. O'Halloran, and A. C. Rosenzweig, Nat Struct Biol 7, $766(2000)$.

40. T. E. Creighton, "Disulfide bonds between cysteines.," p. 155. IRL Press at Oxford University Press, Oxford, 1993.

41. M. Casadevall and B. Sarkar, J Inorg Biochem 71, 147 (1998).

42. A. J. Brenner and E. D. Harris, Anal Biochem 226, 80 (1995).

43. J. M. Rifkind, L. D. Lauer, S. C. Chiang, and N. C. Li, Biochemistry 15, 5337 (1976).

44. D. N. Heaton, G. N. George, G. Garrison, and D. R. Winge, Biochemistry 40, 743 (2001).

45. P. J. Schmidt, T. D. Rae, R. A. Pufahl, T. Hamma, J. Strain, T. V. O'Halloran, and V. C. Culotta, J Biol Chem 274, 23719 (1999).

46. J. F. Eisses, J. P. Stasser, M. Ralle, J. H. Kaplan, and N. J. Blackburn, Biochemistry 39, 7337 (2000).

47. P. Y. Jensen, N. Bonander, N. Horn, Z. Tumer, and O. Farver, Eur J Biochem 264, 890 (1999).

48. A. L. Lamb, A. S. Torres, T. V. O'Halloran, and A. C. Rosenzweig, Biochemistry 39, 14720 (2000). 
49. F. W. Verheijen, C. E. Beerens, A. C. Havelaar, W. J. Kleijer, and G. M. Mancini, J Med Genet 35, 849 (1998).

50. M. Solioz and A. Odermatt, J Biol Chem 270, 9217 (1995).

51. P. J. Riggle and C. A. Kumamoto, J Bacteriol 182, 4899 (2000). 


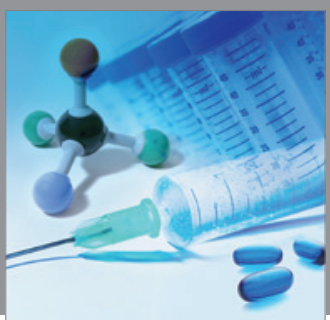

International Journal of

Medicinal Chemistry

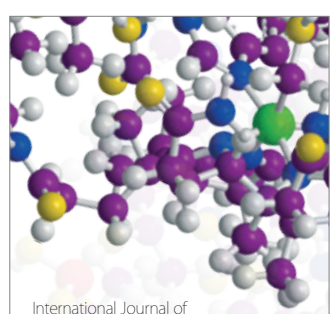

Carbohydrate Chemistry

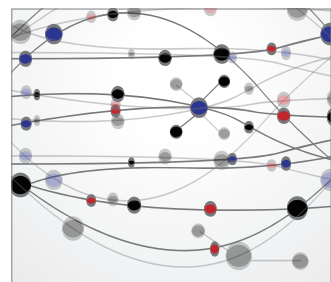

The Scientific World Journal
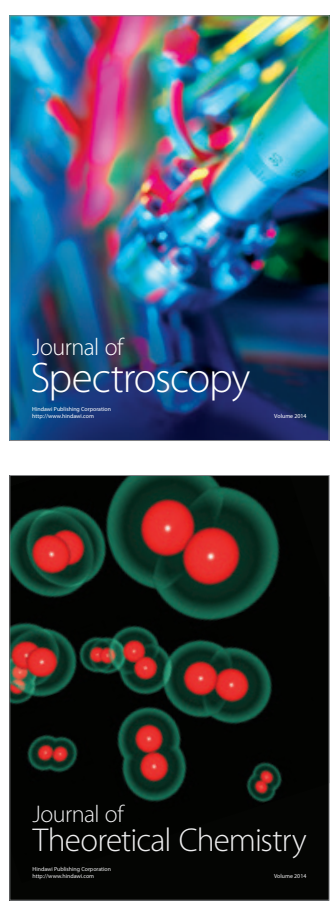
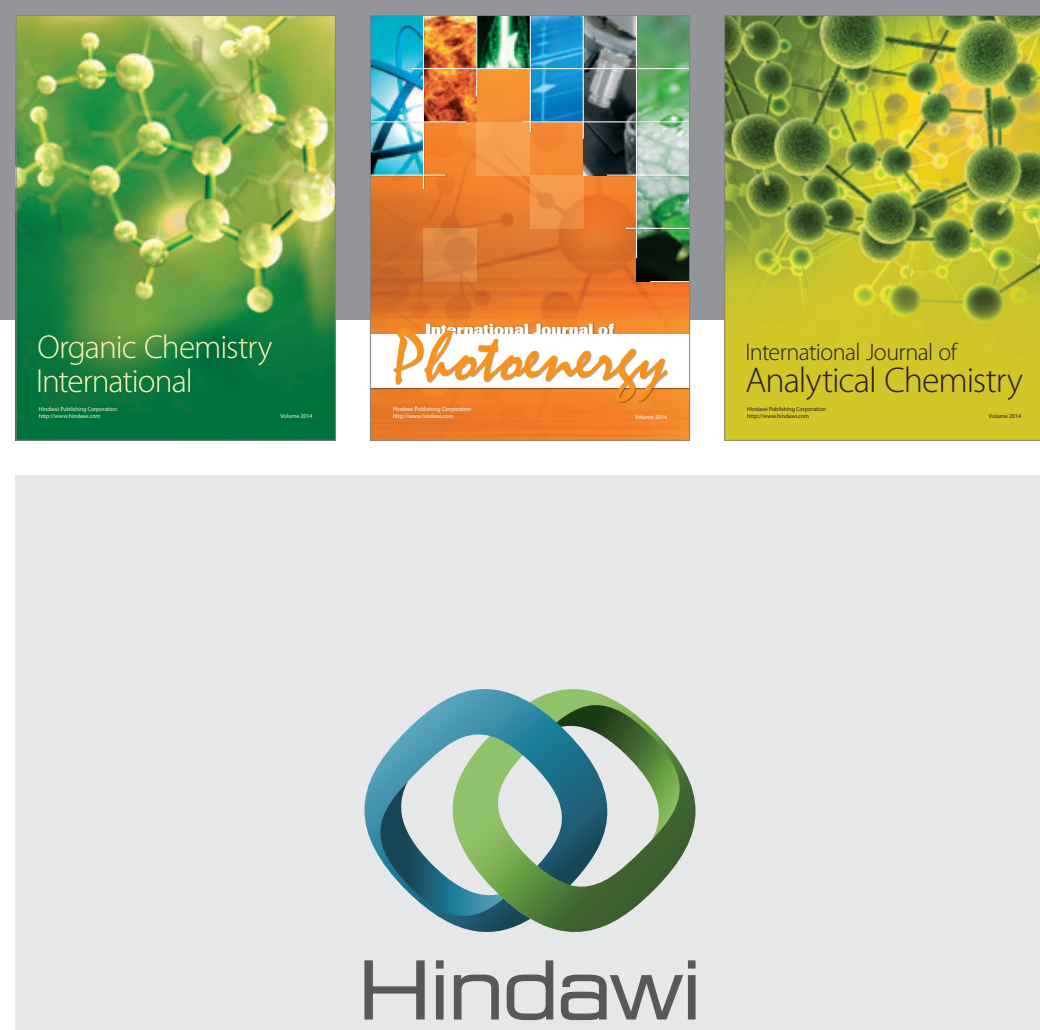

Submit your manuscripts at

http://www.hindawi.com
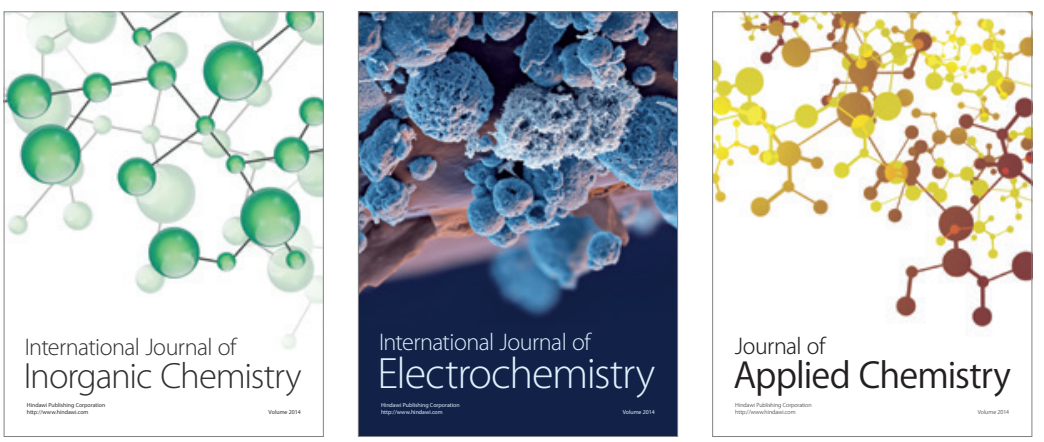

Journal of

Applied Chemistry
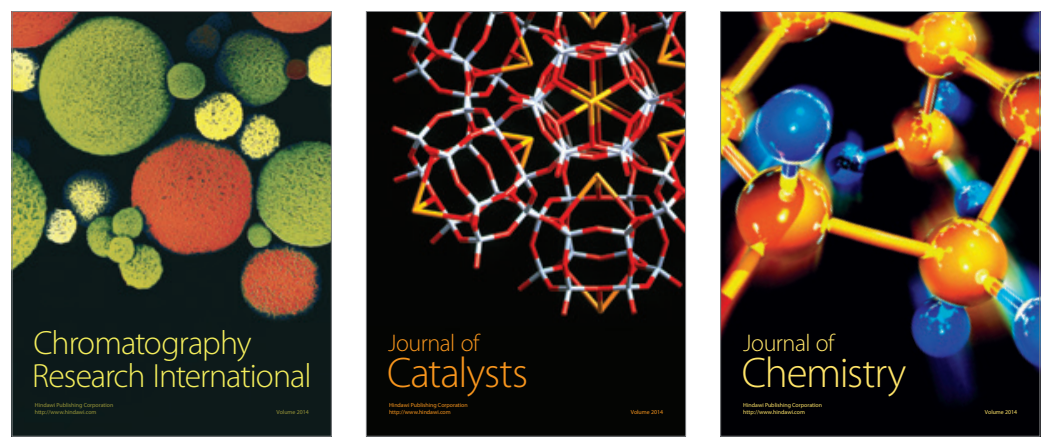
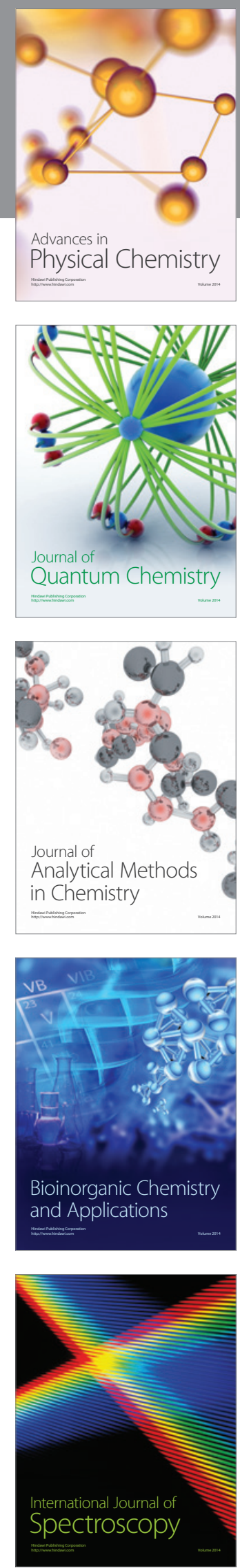